\title{
HPLC Analysis of Fatty Acyl-Glycine in the Aqueous Methanesulfonic Acid Hydrolysates of N-Terminally Fatty Acylated Peptides ${ }^{1,2)}$
}

\author{
Keiko Okimura, Kazuhiro Ohki, Sotoo Nagai, and Naoki SaKura* \\ Faculty of Pharmaceutical Sciences, Hokuriku University; Kanagawa-machi, Kanazawa 920-1181, Japan. \\ Received March 7, 2003; accepted May 6, 2003
}

\begin{abstract}
Acylation with long-chain fatty acids is a common modification at the $\mathrm{N}$-terminal glycine residues of natural proteins. In this work, we performed HPLC analysis of myristoylglycine (Myr-Gly-OH), palmitoylglycine (PalGly-OH) or lauroylglycine (Lau-Gly-OH), which were produced in the hydrolysates of synthetic Myr-Gly-, PalGly-, or Lau-Gly-peptides, respectively, by means of a mild acid hydrolysis in methanesulfonic acid : dioxane : water $(2: 1: 1)$ at $60^{\circ} \mathrm{C}$ for $12 \mathrm{~h}$. Myr-Gly-OH, Pal-Gly-OH and Lau-Gly-OH were quite stable under hydrolysis conditions. These fatty acyl-Gly-OH were conveniently detectable at a $20 \mathrm{nmol}$ level by direct reversed-phase HPLC. Thus, mild acid hydrolysis, followed by HPLC analysis of the hydrolysate, provides a simple method of identification of the N-terminal structure of fatty acyl-Gly-peptides.
\end{abstract}

Key words myristoylglycine; N-terminal; modification; methanesulfonic acid; hydrolysis; HPLC analysis

Acylation at the N-terminus is a common modification in natural proteins. ${ }^{3-6)}$ Myristic acid (Myr-OH) or other longchain fatty acids, such as lauric acid $(\mathrm{Lau}-\mathrm{OH})^{7-10)}$ and palmitic acid $(\mathrm{Pal}-\mathrm{OH}),{ }^{11)}$ in rare cases, are found in amide linkage with the N-terminal Gly residue of proteins. The acylation by $\mathrm{Myr}-\mathrm{OH}$ is catalyzed by $N$-myristoyl transferases, which have been identified and characterized. These enzymes catalyze transfer of Myr specifically to the N-terminal Gly of proteins, and require the consensus sequence Gly-X-X-XSer/Thr as a substrate. ${ }^{3)}$ An N-terminal Gly residue is an absolute requirement for enzymatic myristoylation, and the resulting Myr moiety in the modified protein plays an important role in membrane binding. ${ }^{3)}$ Determination of the structure of N-terminally modified proteins or peptides is laborious, because the blocking groups prevent straightforward application of amino acid sequence determination methods such as Edman degradation on the intact protein or peptides. To date, various methods have been reported to determine the structure of the Myr moiety at the N-terminally blocked peptides, namely, incorporation of $\left[{ }^{3} \mathrm{H}\right] \mathrm{Myr}-\mathrm{OH}$ to obtain a labeled protein, ${ }^{12-14)}$ enzymatic removal of $\mathrm{Myr}-\mathrm{OH}$ from blocked peptides, ${ }^{15)}$ identification of Myr-Gly-OH after mild acid hydrolysis followed by chemical derivatization ${ }^{16)}$ and mass spectrometry. ${ }^{17-20)}$

We have already investigated the susceptibility and stability of the internal peptide linkage of model peptides MyrGly-X-Phe-OH ( $\mathrm{X}=$ various amino acids) under mild acid hydrolysis conditions. ${ }^{21)}$ Regioselective cleavage of the Gly$\mathrm{X}$ peptide bond was shown in the presence of a high concentration of aqueous methanesulfonic acid (MSA) by HPLC analysis of $\mathrm{H}-\mathrm{X}-\mathrm{Phe}-\mathrm{OH}$ as the major peak. Here, we report that Myr-Gly-OH, a counterpart of H-X-Phe-OH, produced from Myr-Gly-X-Phe-OH can be analyzed directly by reversed-phase HPLC (RP-HPLC) almost quantitatively, because Myr-Gly-OH is quite stable under the hydrolysis conditions examined here. Thus, the hydrolysis of Myr-Gly-peptides, as well as the other fatty acyl-Gly-peptides, followed by RP-HPLC analysis of fatty acyl-Gly-OH, provides a simple method to deduce the N-terminal structure of blocked peptides.

\section{MATERIALS AND METHODS}

Peptide Synthesis All reagents, solvents and protected amino acids were obtained from Watanabe Chemical Industries, Ltd., Japan, and chloromethylated polystyrene resin ( $1 \%$ divinylbenzene, $0.66 \mathrm{mmol} / \mathrm{g}$ ) was from Peptide Institute Inc., Japan. Starting from Boc-amino acid-resin, protected peptides were constructed by a standard solid-phase method employing an ABI 433A peptide synthesizer (Applied Biosystems, U.S.A.). The side chain protecting groups of $N^{\alpha}$-Boc amino acids were $p$-tosyl (Tos) for the guanidino group of Arg, $N^{\pi}$-benzyloxymethyl (Bom) for the imidazole ring of His, 2-chlorobenzyloxylcarbonyl (Cl-Z) for the $\varepsilon$-amino group of Lys, and $O$-benzyl (Bzl) for the hydroxy groups of Thr and Ser. Deprotection of the $N^{\alpha}$-Boc group was accomplished using 33\% trifluoroacetic acid (TFA) in dichloromethane (DCM) for $30 \mathrm{~min}$. A coupling reaction was performed for $2 \mathrm{~h}$ employing $N^{\alpha}$-Boc-amino acids (3 eq) and 2-(1H-benzotriazole-1-yl)-1,1,3,3-tetramethyluronium hexafluorophosphate $^{22)}$ (HBTU reagent, 3 eq) in the presence of 1-methylmorpholine (4.5 eq) in $N$-methylpyrrolidone (NMP). Boc-Gln was coupled exclusively by the dicyclohexylcarbodiimide (DCC)-1-hydroxybenzotriazole (HOBt) method.

The protected peptide resin was treated with anhydrous liquid hydrogen fluoride (HF) containing $10 \%$ anisole at -5 to $0{ }^{\circ} \mathrm{C}$ for $45 \mathrm{~min}$ in a Teflon HF apparatus (Peptide Institute Inc., Japan). After evaporation of HF in vacuo with ice-cooling, the residual mixture was washed with ether prior to extraction of the fatty acylated peptide with aqueous dioxane or $50 \%$ acetic acid to give the crude peptide.

Purification and Characterization The synthetic fatty acyl-peptides were highly purified by RP-HPLC on a column of YMC-pack D-ODS-5-ST S-5 $120 \AA(20 \times 150 \mathrm{~mm})$ with $0.1 \%$ TFA-acetonitrile $(\mathrm{MeCN})$ solvent system in an isocratic manner, followed by gel-filtration on a column of Toyopearl HW-40 (super fine) $(1.5 \times 47 \mathrm{~cm}$, Tosoh Co., Japan) with $12 \%$ acetic acid or $70-100 \%$ methyl alcohol as an eluent. Homogeneity of the purified peptides was confirmed by analytical RP-HPLC on a column of Puresil C18 $(4.6 \times 250 \mathrm{~mm})$ with a $0.1 \%$ TFA-MeCN solvent system, and high-performance thin-layer chromatography (HP-TLC, Kieselgel 60, E. Merck, 
Table 1. FAB-MS Data of Synthetic Peptides

\begin{tabular}{|c|c|c|}
\hline \multirow{2}{*}{ Peptide } & \multicolumn{2}{|c|}{ FAB-MS } \\
\hline & Found $[\mathrm{M}+\mathrm{H}]^{+}$ & Formula \\
\hline Myr-Gly-OH ${ }^{a)}$ & 286 & $\mathrm{C}_{16} \mathrm{H}_{31} \mathrm{NO}_{3}$ \\
\hline Pal-Gly-Ala-Phe-OH & 532 & $\mathrm{C}_{30} \mathrm{H}_{49} \mathrm{~N}_{3} \mathrm{O}_{5}$ \\
\hline Pal-Gly-OH & 314 & $\mathrm{C}_{18} \mathrm{H}_{35} \mathrm{NO}_{3}$ \\
\hline Lau-Gly-Ala-Phe-OH & 476 & $\mathrm{C}_{26} \mathrm{H}_{41} \mathrm{~N}_{3} \mathrm{O}_{5}$ \\
\hline Lau-Gly-OH & 258 & $\mathrm{C}_{14} \mathrm{H}_{27} \mathrm{NO}_{3}$ \\
\hline Peptide 1 & 827 & $\mathrm{C}_{38} \mathrm{H}_{70} \mathrm{~N}_{10} \mathrm{O}_{10}$ \\
\hline Peptide 2 & 1950 & $\mathrm{C}_{93} \mathrm{H}_{153} \mathrm{~N}_{21} \mathrm{O}_{24}$ \\
\hline
\end{tabular}

a) Ref. 21 .

Table 2. Characteristics of Synthetic Peptides

\begin{tabular}{|c|c|c|c|c|}
\hline \multirow{2}{*}{ Peptide } & \multirow{2}{*}{$\begin{array}{c}{[\alpha]_{\mathrm{D}}^{24}} \\
(c=0.5)^{a)}\end{array}$} & \multirow{2}{*}{$\frac{\mathrm{RP}^{\left.-\mathrm{HPLC}^{c}\right)}}{t_{\mathrm{R}}(\mathrm{min})}$} & \multicolumn{2}{|c|}{$\left.\mathrm{HP} \mathrm{TLC}^{d}\right)$} \\
\hline & & & $R f^{1}$ & $R f^{2}$ \\
\hline Pal-Gly-Ala-Phe-OH & -5.9 & 27.0 & 0.70 & 0.73 \\
\hline Pal-Gly-OH & - & 26.7 & 0.68 & 0.75 \\
\hline Lau-Gly-Ala-Phe-OH & -3.7 & 16.4 & 0.70 & 0.73 \\
\hline Lau-Gly-OH & - & 15.1 & 0.66 & 0.75 \\
\hline Peptide 1 & $-39.6^{b)}$ & 9.7 & 0.50 & 0.40 \\
\hline Peptide 2 & -29.7 & 10.5 & 0.55 & 0.40 \\
\hline
\end{tabular}

a) In DMF. b) $c=0.1$. c) HPLC conditions: column, Puresil C18 $(4.6 \times 250$ $\mathrm{mm}$ ); elution, $61.75-81.75 \% \mathrm{MeCN}$ in $0.1 \% \mathrm{TFA}$; flow rate, $1 \mathrm{ml} / \mathrm{min}$; detection, $210 \mathrm{~nm}$; gradient. d) $R f^{1}, n-\mathrm{BuOH}:$ pyridine : $\mathrm{AcOH}: \mathrm{H}_{2} \mathrm{O}(30: 20: 6: 24) ; R f^{2}, n$ $\mathrm{BuOH}:$ AcOEt : $\mathrm{AcOH}: \mathrm{H}_{2} \mathrm{O}(1: 1: 1: 1)$.

Germany) with two solvent systems. FAB-MS analysis was conducted on a JMS-DX300 mass spectrometer (JEOL, Ltd., Japan). Optical rotations of the peptides were measured with a $3.5 \times 50 \mathrm{~mm}$ cell with a GIP-370 digital polarimater (Nippon Bunko Co., Ltd., Japan). The analytical data are shown in Tables 1 and 2.

HPLC Analysis of Fatty Acylglycine in MSA-hydrolysate MSA for hydrolysis of peptides was purchased from Wako, Japan and dioxane (analytical grade) was obtained from Nacalai Tesque, Japan. These reagents were employed without further purification. To analyze acid hydrolysates, $4 \times 10^{-4} \mathrm{~mol} / 1$ peptide solution $(50 \mu \mathrm{l})$ in MSA : water: dioxane $(2: 1: 1)$ was prepared in a glass tube with a tight cap on ice. These were maintained at $60^{\circ} \mathrm{C}$ for $12 \mathrm{~h}$. After hydrolysis, each tube was diluted with dioxane: water $(1: 1)(66.5 \mu \mathrm{l})$ and neutralized with $8 \mathrm{~mol} / \mathrm{l} \mathrm{NaOH}$ : dioxane $(1: 1)(50 \mu \mathrm{l})$ on ice, then stored at $-40^{\circ} \mathrm{C}$ until analysis. An aliquot of the solution was injected onto a column of YMCPack C4 $(4.6 \times 150 \mathrm{~mm})$, which was eluted by a linear gradient of 28.5 to $95 \% \mathrm{MeCN}$ in $0.1 \%$ TFA over a period of $15 \mathrm{~min}$ at a flow rate of $1 \mathrm{ml} / \mathrm{min}$. The peak was monitored at $210 \mathrm{~nm}$.

\section{RESULTS}

As reported previously, ${ }^{21)}$ the major hydrolytic cleavage of Myr-Gly-X-Phe-OH in MSA : water: dioxane $(2: 1: 1)$ at $60{ }^{\circ} \mathrm{C}$ for $3 \mathrm{~h}$ occurred at the Gly-X bond to give X-Phe-OH. In this study, direct RP-HPLC of Myr-Gly-OH, a counterpart of $\mathrm{X}-\mathrm{Phe}-\mathrm{OH}$, in the hydrolysate was examined by measuring the eluate at $210 \mathrm{~nm}$. After the large peaks of MSA and dioxane, the peak of Myr-Gly-OH appeared at $15.6 \mathrm{~min}$ from a

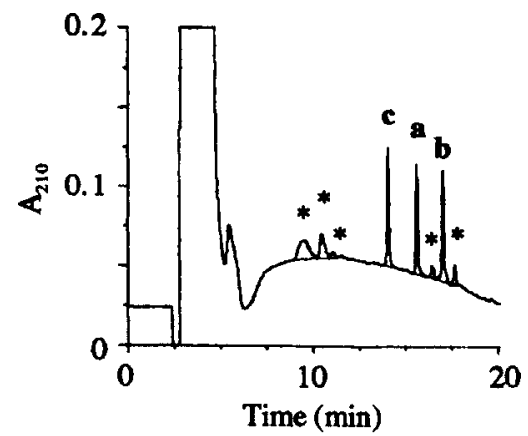

Fig. 1. RP-HPLC Profiles of $20 \mathrm{nmol}$ Each of Standard Myr-Gly-OH (a), Pal-Gly-OH (b) and Lau-Gly-OH (c) in a MSA: Water: Dioxane $(2: 1: 1)$ Solution after $12 \mathrm{~h}$ Incubation at $60^{\circ} \mathrm{C}$ Followed by Neutralization

* Marks are due to the reagents.

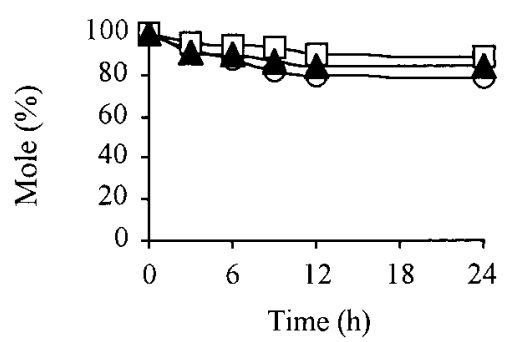

Fig. 2. Stability of Myr-Gly-OH (O), Lau-Gly-OH ( $\square$ ) or Pal-Gly-OH (ム) during Incubation in MSA : Water : Dioxane $(2: 1: 1)$ at $60^{\circ} \mathrm{C}$ for $24 \mathrm{~h}$
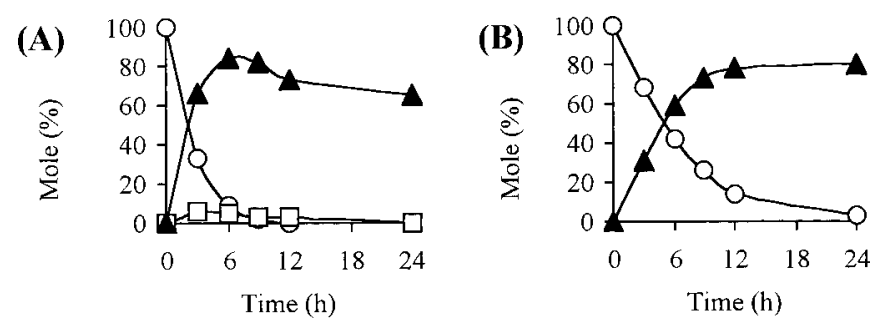

Fig. 3. Time Course of Changes in Concentration of Myr-Gly-X-Phe-OH (A; $\mathrm{X}=\mathrm{Ala}, \mathrm{B} ; \mathrm{X}=\mathrm{Ile}$ ) and Their Hydrolysates during Incubation in MSA : Water : Dioxane $(2: 1: 1)$ at $60^{\circ} \mathrm{C}$ for $24 \mathrm{~h}$

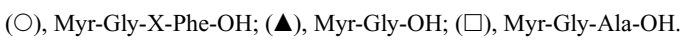

$\mathrm{C}_{4}$-column by linear gradient elution of 28.5 to $95 \% \mathrm{MeCN}$ in $0.1 \%$ TFA over a period of $15 \mathrm{~min}$ (Fig. 1). Under the same HPLC conditions, Pal-Gly-OH $\left(t_{\mathrm{R}} 17.0 \mathrm{~min}\right)$ and LauGly-OH $\left(t_{\mathrm{R}} 14.0 \mathrm{~min}\right)$ could be detected as seen in Fig. 1. Thus, it was found that these fatty acyl-Gly-OH could be analyzed at $20 \mathrm{nmol}$, although several unknown peaks appeared which were derived from the reagents.

Next, the stability of fatty acyl-Gly-OH was examined under mild hydrolysis conditions in MSA: water: dioxane $(2: 1: 1)$ at $60^{\circ} \mathrm{C}$ to determine when the highest concentration of fatty acyl-Gly-OH exists in the hydroysates of fatty acyl-peptides. Time courses of the degradation of Myr-Gly$\mathrm{OH}$, Pal-Gly-OH and Lau-Gly-OH in an incubation solution of MSA: water: dioxane $(2: 1: 1)$ were examined at $60^{\circ} \mathrm{C}$. As shown in Fig. 2, around $80 \%$ of these fatty acyl-Gly-OH survived intact even after $24 \mathrm{~h}$.

On the other hand, incubation of Myr-Gly-Ala-Phe-OH in MSA : water : dioxane $(2: 1: 1)$ at $60^{\circ} \mathrm{C}$ caused almost complete decomposition after $12 \mathrm{~h}$, yielding about $70 \%$ of MyrGly-OH (Fig. 3A). When Myr-Gly-Ile-Phe-OH, containing 
one of the most steric amino acids, Ile, was treated under the same conditions, $20 \%$ of the starting material remained intact after $12 \mathrm{~h}$, most of which disappeared after $24 \mathrm{~h}$ as shown in Fig. 3B. Pal-Gly-Ala-Phe-OH and Lau-Gly-Ala-Phe-OH also almost completely decomposed after $12 \mathrm{~h}$, yielding more than $60 \%$ of Pal-Gly-OH and $70 \%$ of Lau-Gly-OH, respectively (Fig. 4). Thus, fatty acyl-Gly-OH was released from fatty acyl-Gly-peptides in high yields by $12 \mathrm{~h}$ hydrolysis and was detectable by direct RP-HPLC. Yields of Myr-Gly-OH, Pal-Gly-OH and Lau-Gly-OH derived from various fatty acyl-Gly-peptides in $12 \mathrm{~h}$-hydrolysis in MSA : water : dioxane $(2: 1: 1)$ at $60^{\circ} \mathrm{C}$ are summarized in Table 3 . Synthetic peptides of Myr-Gly-Ala-Gln-Val-Ser-Arg-OH (1) and Myr-GlyGln-Thr-Val-Thr-Thr-Pro-Leu-Ser-Leu-Thr-Leu-Gly-HisTrp-Lys-OH (2) used in this study correspond to the N-terminal tryptic fragments of HRV(1B)VP4 ${ }^{23)}$ and MuLVgag, ${ }^{24}$ respectively. Peptides $\mathbf{1}$ and $\mathbf{2}$ decomposed very rapidly in MSA : water : dioxane $(2: 1: 1)$ at $60^{\circ} \mathrm{C}$, and $20 \mathrm{nmol}$ equivalent of Myr-Gly-OH in the incubation solution could be detected on HPLC chromatograms after $12 \mathrm{~h}$-hydrolysis, as seen in Fig. 5.
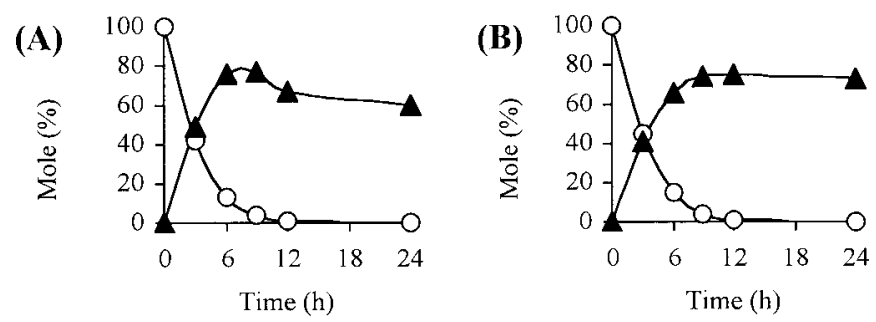

Fig. 4. Time Course of Changes in Concentration of Y-Gly-Ala-Phe-OH (A; $\mathrm{Y}=\mathrm{Pal}, \mathrm{B} ; \mathrm{Y}=\mathrm{Lau}$ ) and Their Hydrolysates during Incubation in MSA : Water: Dioxane $(2: 1: 1)$ at $60^{\circ} \mathrm{C}$ for $24 \mathrm{~h}$

(O), Y-Gly-Ala-Phe-OH; (A), Y-Gly-OH.

Table 3. Yields of Y-Gly-OH (Y=Myr, Pal or Lau) Derived from Y-GlyPeptides at $60^{\circ} \mathrm{C}$ after $12 \mathrm{~h}$ Hydrolysis in MSA : Water : Dioxane $(2: 1: 1)$

\begin{tabular}{lc}
\hline \hline Peptide & Mole (\%) of Y-Gly-OH \\
\hline Myr-Gly-Ala-Phe-OH & 83.1 \\
Myr-Gly-Ile-Phe-OH & 77.3 \\
Peptide 1 & 79.9 \\
Peptide 2 & 80.2 \\
Pal-Gly-Ala-Phe-OH & 67.4 \\
Lau-Gly-Ala-Phe-OH & 74.8 \\
\hline
\end{tabular}

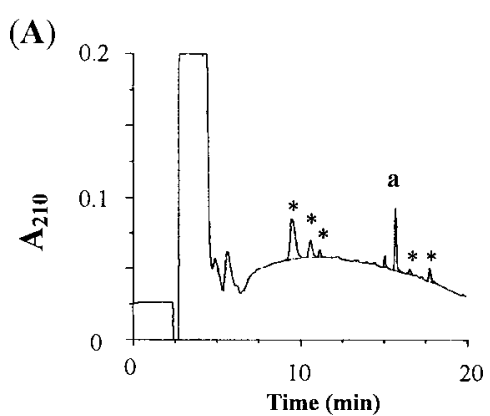

\section{DISCUSSION}

In our previous study, ${ }^{21)}$ a simple deblocking method for Myr-Gly-peptide (Myr-Gly-X-Phe-OH, X=various amino acids) was examined to obtain $\mathrm{H}-\mathrm{X}-\mathrm{Phe}-\mathrm{OH}$ as a main product in the hydrolysate. Therefore, mild hydrolysis conditions were investigated for regioselective cleavage of the Gly-X bond, which was performed in a high concentration of aqueous MSA at $25^{\circ} \mathrm{C}$ or $60^{\circ} \mathrm{C}$ within $6 \mathrm{~h}$. However, when $\mathrm{X}$ was Gln or Asn, many peaks were observed on HPLC examination of the hydrolysates and neither H-Gln-Phe-OH nor HAsn-Phe-OH was the main product. In the case of peptide 1 and 2, hydrolysis in MSA: water: dioxane $(2: 1: 1)$ at $60^{\circ} \mathrm{C}$ for $6 \mathrm{~h}$ produced numerous peaks, among which those of des[Myr-Gly]-peptides, namely, H-Ala-Gln-Val-Ser-Arg-OH and H-Gln-Thr-Val-Thr-Thr-Pro-Leu-Ser-Leu-Thr-Leu-GlyHis-Trp-Lys-OH, were not observed. Since both peptides 1 and 2 contain Ser and/or Thr, the internal peptide bonds might have been cleaved at the N-terminal of Ser and Thr via $\mathrm{N}$ to $\mathrm{O}$ acyl migration in MSA : water: dioxane $(2: 1: 1)$ to give complex products. A similar degradation of peptide was reported in a short communication; hydrolysis of LH-RH, pGlu ${ }^{1}$-His-Trp-Ser-Tyr-Gly-Leu-Arg-Pro-Gly- $\mathrm{NH}_{2}$, in $70 \%$ MSA, gave not only des-pGlu-peptide, but also LH-RH (410) by cleavage of the peptide bond at the N-terminal of $\mathrm{Ser}^{4}$ of LH-RH. ${ }^{25}$ Thus, aqueous high concentration MSA hydrolysis may not be applicable for obtaining des-[Myr-Gly]-peptide as the main product, which could be applied to Edman degradation. Nevertheless, the MSA hydrolysis could be applicable to selective removal of fatty acyl-Gly-OH such as Myr-Gly-OH, which was quite stable under the hydrolysis conditions, as demonstrated in this study. It was also reported by Goddard and Felsted ${ }^{16)}$ that the relative hydrolysis rate of Myr-Gly-OH to H-Gly-Gly-OH was 0.099 under mild acid hydrolysis conditions at $100^{\circ} \mathrm{C}$ in $0.05 \mathrm{M} \mathrm{HCl}$. Therefore, our attention focused only on analyzing fatty acyl-Gly-OH in the hydrolysate to obtain structural information on the modified peptides with long-chain fatty acids. For HPLC analysis of fatty acyl-Gly-OH, it was advantageous to decompose various peptides produced by hydrolysis to amino acids. Taking into account the stability of fatty acyl-Gly-OH, hydrolysis conditions in MSA: water: dioxane $(2: 1: 1)$ at $60^{\circ} \mathrm{C}$ for $12-24 \mathrm{~h}$ was recommended. Fatty acyl-Gly-OH was analyzed directly by RP-HPLC of the hydrolysate of blocked peptide and the peak measured at $210 \mathrm{~nm}$ was detectable at a $20 \mathrm{nmol}$ level in this study. The detection limit of the peak of fatty acyl-Gly-OH may be improved by application of LC-

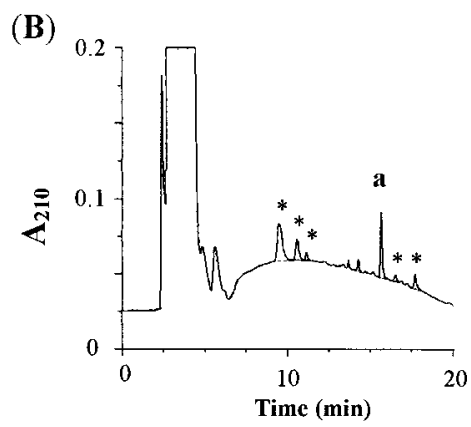

Fig. 5. RP-HPLC Profiles of Myr-Gly-OH (a) Obtained by Injection of $20 \mathrm{nmol}$ of Peptide $\mathbf{1}$ (A) or 2 (B) Acid Hydrolysate Following $12 \mathrm{~h}$ Hydrolysis 
MS analysis, because in the literature ${ }^{17-19)} 0.8-10 \mathrm{nmol}$ of peptides was used to identify N-terminal Myr-Gly-OH by mass spectrometry.

The results of the present study can be summarized as follows: 1) Myr-Gly-OH is cleaved out predominantly from Myr-Gly-peptides by mild hydrolysis in the presence of a high concentration of MSA; 2) Myr-Gly-OH is stable under hydrolysis conditions; and 3) Myr-Gly-OH, as well as PalGly-OH and Lau-Gly-OH, can be identified by direct RPHPLC at $20 \mathrm{nmol}$. This method could be applied to identify $\mathrm{N}$-terminal fatty acylglycine directly from the hydrolysates of $\mathrm{N}$-terminal blocked peptides by long-chain fatty acids, which could be prepared as enzymatic peptide fragments by the endopeptidases trypsin or chymotrypsin.

Acknowledgement This work was supported in part by a grant from The Specific Research Fund of Hokuriku University.

\section{REFERENCES AND NOTES}

1) With the exception of glycine, the amino acids and their derivatives mentioned in this paper were of the L-configuration. The abbreviations for amino acids and peptides are in accordance with the rules of the IUPAC-IUB Commission on Biochemical Nomenclature in Eur. J. Biochem., 138, 9-37 (1984).

2) A part of this work was reported previously as a preliminary communication: Okimura K., Ohki K., Nagai S., Sakura, N., "Peptide Science 2000," ed. by Shioiri T., The Japanese Peptide Society, Osaka, 2001, pp. $413-416$.

3) Resh M. D., Biochim. Biophys. Acta, 1451, 1-16 (1999).

4) Knoll L. J., Johnson D. R., Bryant M. L., Gordon, J. I., Methods Enzymol., 250, 405-435 (1995).

5) Gordon J. I., Duronio, R. J., Rudnick D. A., Adams S. P., Gokel G. W., J. Biol. Chem., 266, 8647-8650 (1991).
6) Towler D. A., Gordon J. I., Adams S. P., Glaser L., Ann. Rev. Biochem., 57, 69-99 (1988).

7) Kokame K., Fukada Y., Yoshizawa T., Takao T., Shimonishi Y., Nature (London), 359, 749-752 (1992).

8) Neubert T. A., Johnson R. S., Hurley J. B., Walsh K. A., J. Biol. Chem., 267, 18274-18277 (1992).

9) Dizhoor A. M., Ericsson L. H., Johnson R. S., Kumar S., Olshevskaya E., Zozulya S., Neubert T. A., Stryer L., Hurley J. B., Walsh K. A., J. Biol. Chem., 267, 16033-16036 (1992).

10) Johnson R. S., Ohguro H., Palczewski K., Hurley J. B., Walsh K. A., Neubert T. A., J. Biol. Chem., 269, $21067-21071$ (1994).

11) Kleuss C., Krause E., EMBO J., 22, 826-832 (2003).

12) Paul A. V., Schultz A., Pincus S. E., Oroszlan S., Wimmer E., Proc. Natl. Acad. Sci. U.S.A., 84, 7827-7831 (1987).

13) Chow M., Moscufo N., Methods Enzymol., 250, 495-509 (1995).

14) Aspbury R. A., Fisher M. J., Rees H. H., Biochim. Biophys. Acta, 1382, $111-119$ (1998).

15) Misumi S., Tsuruta M., Furuishi K., Shoji S., Biochem. Biophys. Res. Commun., 217, 632-639 (1995).

16) Goddard C., Felsted R. L., Biochem. J., 253, 839-843 (1988).

17) Ozols J., Carr S. A., Strittmatter P., J. Biol. Chem., 259, 13349-13354 (1984).

18) Aitken A., Cohen P., Santikarn S., Williams D. H., Calder A. G., Smith A., Klee C. B., FEBS Lett., 150, 314-318 (1982).

19) Carr S. A., Biemann K., Shoji S., Parmelee D. C., Titani K., Proc. Natl. Acad. Sci. U.S.A., 79, 6128-6131 (1982).

20) Takasaki A., Hayashi N., Matsubara M., Yamauchi E., Taniguchi H., J. Biol. Chem., 274, 11848-11853 (1999).

21) Okimura K., Sugimoto K., Ohki K., Sakura N., Hashimoto T., Chem. Pharm. Bull., 47, 1249-1255 (1999).

22) Knorr R., Trzeciak A., Bannworth W., Gillessen D., Tetrahedron Lett., 30, 1927-1930 (1989).

23) Chow M., Newman J. F. E., Filman D., Hogle J. M., Rowlands D. J., Brown F., Nature (London), 327, 482-486 (1987).

24) Henderson L. E., Krutzsch H. C., Oroszlan S., Proc. Natl. Acad. Sci. U.S.A., 80, 339-343 (1983).

25) Kobayashi J., Ohki K., Sakura N., Hashimoto T., "Peptide SciencePresent and Future," ed. by Shimonishi Y., Kluwer Academic Publishers, U.K., 1999, pp. 157-159. 